\title{
DNA Barcoding and Morphological Identification of Spiny Lobsters in South Korean Waters: A New Record of Panulirus longipes and Panulirus homarus homarus
}

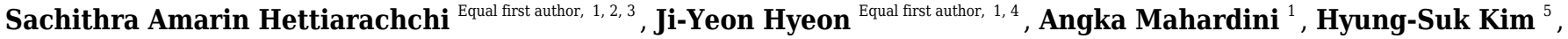 \\ Jun-Hwan Byun ${ }^{1}$, Han-Jun Kim ${ }^{6}$, Jong-Gyun Jeong ${ }^{7}$, Jung-Kyu Yeo ${ }^{7}$, Shin-Kwon Kim ${ }^{8}$, Se-Jae Kim ${ }^{4}$, Youn-Seong \\ Heo $^{7}$, Jonathan Sathyadith ${ }^{1,3}$, Do-Hyung Kang ${ }^{1,3}$, Sung-Pyo Hur ${ }^{\text {Corresp. } 1,3}$ \\ 1 Jeju Marine Research Center, Korea Institute of Ocean Science and Technology (KIOST), 2670, Iljudongoro, Gujwa, Jeju, 63349, Republic of Korea \\ 2 Department of Fisheries and Aquaculture, Faculty of Fisheries and Marine Sciences \& Technology, University of Ruhuna, Matara, Sri Lanka \\ 3 Department of Ocean Science, University of Science and Technology, 217 Gajeong ro, Yuseong gu, Daejeon, Republic of Korea \\ 4 Department of Biology, Jeju National University, Jeju, 102 Jejudaehak-ro, Jeju, 63243, Republic of Korea \\ 5 Department of Kinesiology, Jeju National University, Jeju, 102 Jejudaehak-ro, Jeju, 63243, Republic of Korea \\ 6 Marine Ecosystem Research Center, Korea Institute of Ocean Science \& Technology, Busan, 385 Haeyangro, Yeongdogu, Busan, 49111, Republic of \\ Korea \\ 7 LED-Marine Biology Convergence Technology Research Center, Pukyong national university, Busan, 48547, Republic of Korea \\ 8 Aquaculture Research Division, National Institute of Fisheries Science, Busan, 216 Gijanghaean-ro, Gijang, Republic of Korea \\ Corresponding Author: Sung-Pyo Hur \\ Email address: hursp@kiost.ac.kr
}

To date, 19 species of spiny lobsters from the genus Panulirus have been discovered, of which only $P$. japonicus, $P$. penicilatus, $P$. stimpsoni, and $P$. versicolor have been documented in South Korean waters. In this study, we aimed to identify and update the current list of spiny lobster species that inhabit South Korean waters based on the morphological features and the phylogenetic profile of cytochrome oxidase I (COI) of mitochondrial DNA (mtDNA). Spiny lobsters were collected from the southern and eastern coasts of Jeju Island, South Korea. Phylogenetic analyses were performed using neighborjoining ( $\mathrm{NJ})$, maximum likelihood $(\mathrm{ML})$, and Bayesian inference (BI) methods. The $\mathrm{ML}$ tree was used to determine the spiny lobster lineages, thereby clustering the 17 specimens collected in this study into clades $A, B, C$, and $D$, which were reciprocally monophyletic with $P$. japonicus, $P$. homarus homarus, $P$. longipes, and $P$. stimpsoni, respectively. These clades were also supported by morphological examinations. Interestingly, morphological variations, including the connected pleural and transverse groove at the third abdominal somite, were observed in four specimens that were genetically confirmed as $P$. japonicus. This finding is novel within the $P$. japonicus taxonomical reports. Additionally, this study updates the documentation of spiny lobsters inhabiting South Korean waters as $P$. longipes and $P$. homarus homarus were recorded for the first time in this region. 
1 DNA Barcoding and Morphological Identification of

2 Spiny Lobsters in South Korean Waters: A New

3 Record of Panulirus longipes and Panulirus homarus

4 homarus

5

6

7

8
Sachithra Amarin Hettiarachchi ${ }^{1,2,3, *}$, Ji-Yeon Hyeon ${ }^{1,4,{ }^{*}}$, Angka Mahardini ${ }^{1}$, Hyung-Suk Kim ${ }^{5}$, Jun-Hwan Byun ${ }^{1}$, Han-Jun Kim ${ }^{6}$, Jong-Gyun Jeong ${ }^{7}$, Jung-Kyu Yeo ${ }^{7}$, Shin-Kwon Kim ${ }^{8}$, Se-Jae $\mathrm{Kim}^{4}$, Youn-Seong Heo ${ }^{7}$, Jonathan Sathyadith ${ }^{1,3}$, Do-Hyung Kang ${ }^{1,3}$, Sung-Pyo Hur ${ }^{1,3}$

${ }^{1}$ Jeju Marine Research Center, Korea Institute of Ocean Science and Technology (KIOST), 2670, Iljudongoro, Gujwa, Jeju, 63349, Republic of Korea

${ }^{2}$ Department of Fisheries and Aquaculture, Faculty of Fisheries and Marine Sciences \& Technology, University of Ruhuna, Matara, Sri Lanka

${ }^{3}$ Department of Ocean Science, University of Science and Technology, 217 Gajeong-ro, Yuseong-gu, Daejeon, Republic of Korea ${ }^{4}$ Department of Biology, Jeju National University, 102 Jejudaehak-ro, Jeju, 63243, Republic of Korea

${ }^{5}$ Department of Kinesiology, Jeju National University, 102 Jejudaehak-ro, Jeju, 63243, Republic of Korea

${ }^{6}$ Marine Ecosystem Research Center, Korea Institute of Ocean Science \& Technology, 385 Haeyangro, Yeongdogu, Busan, 49111, Republic of Korea

${ }^{7}$ LED-Marine Biology Convergence Technology Research Center, Pukyong National University, Busan, 48547, Republic of Korea

${ }^{8}$ Aquaculture Research Division, National Institute of Fisheries Science, 216 Gijanghaean-ro, Gijang, Busan 46083, Republic of Korea

*These authors contributed equally to this work.

Corresponding Author:

Sung-Pyo Hur ${ }^{1,2}$

Jeju Marine Research Center, Korea Institute of Ocean Science and Technology (KIOST), 2670, Iljudongoro, Gujwa, Jeju, 63349, Republic of Korea

Email address: hursp@kiost.ac.kr 


\section{Abstract}

40 To date, 19 species of spiny lobsters from the genus Panulirus have been discovered, of which

41 only P. japonicus, $P$. penicilatus, $P$. stimpsoni, and $P$. versicolor have been documented in South

42 Korean waters. In this study, we aimed to identify and update the current list of spiny lobster

43 species that inhabit South Korean waters based on the morphological features and the

44 phylogenetic profile of cytochrome oxidase I (COI) of mitochondrial DNA (mtDNA). Spiny

45 lobsters were collected from the southern and eastern coasts of Jeju Island, South Korea.

46 Phylogenetic analyses were performed using neighbor-joining (NJ), maximum likelihood (ML),

47 and Bayesian inference (BI) methods. The ML tree was used to determine the spiny lobster

48 lineages, thereby clustering the 17 specimens collected in this study into clades $\mathrm{A}, \mathrm{B}, \mathrm{C}$, and D,

49 which were reciprocally monophyletic with $P$.japonicus, $P$. homarus homarus, $P$. longipes, and

50 P. stimpsoni, respectively. These clades were also supported by morphological examinations.

51 Interestingly, morphological variations, including the connected pleural and transverse groove at

52 the third abdominal somite, were observed in four specimens that were genetically confirmed as

53 P.japonicus. This finding is novel within the $P$. japonicus taxonomical reports. Additionally,

54 this study updates the documentation of spiny lobsters inhabiting South Korean waters as $P$.

55 longipes and $P$. homarus homarus were recorded for the first time in this region.

\section{Introduction}

58 Studies on the taxonomical status of spiny lobsters have been conducted throughout the Indian,

59 Pacific, and Atlantic Oceans. Nineteen species from the genus Panulirus have been discovered in

60 these regions, of which seven species have been found within the East China Sea (Holthuis,

61 1991), including P. japonicus, P. penicilatus, $P$. stimpsoni, and $P$. versicolor in South Korean

62 waters (Kim et al., 2009). This genus can be identified based on their transverse ridges with 
63 clear-cut connections and decalcified areas on the female sternum. In male lobsters, variations

64 can be observed in the copulatory ornamentation and setation (George, 2005).

65 In addition to morphological observations, genetic information, such as the mitochondrial

66 cytochrome oxidase subunit I (COI) mitochondrial DNA (mtDNA), is used to identify unknown

67 and novel specimens (Meyer \& Paulay, 2005). Marine fauna diversity can be assessed using the

68 COI mtDNA through a technique known as DNA barcoding. DNA barcoding has also been used

69 for conservation purposes, such as phylogeographic analysis, invasive species detection, and

70 forensic studies (Meyer \& Paulay, 2005; Bucklin et al., 2011; Senevirathna \& Munasinghe,

71 2013; Sembiring et al., 2015; Leray \& Knowlton, 2016). Phylogenetic studies on spiny lobsters

72 have classified them into four (I-IV) non-formal genetic clades (Ptacek et al., 2001). In addition,

73 phylogeographic analysis based on the $P$. homarus mtDNA profile has suggested discrimination

74 between the western (parapatric isolation, secondary contact, and introgression) and eastern

75 (active peripheral speciation) populations (Farhadi et al., 2017).

76 Documenting biodiversity is an essential step that could improve the management and

77 conservation of sustainable natural resources. In South Korea, biodiversity studies have been

78 conspicuously initiated since 2007, following the establishment of the National Institute of

79 Biological Resources (NIBR). Consequently, several new species have been discovered in South

80 Korea, and this number is expected to increase continuously, with a potential for recording up to

8160,000 species by 2020 (Biodiversity Division, Nature Conservation Bureau, Ministry of

82 Environment, 2014). In the case of marine fishes, Kim (2009) reported that approximately five

83 described species are documented for the first time within the Korean Peninsula every year.

84 Meanwhile, in 2018, 76 species of epibenthic invertebrates were documented within the southern

85 part of the East Sea, Korea and $\sim 61 \%$ of these were identified as decapods (Park \& Huh, 2018). 
86 As part of the general biodiversity documentation, this study aimed to update the existing records

87 by identifying spiny lobster species inhabiting South Korean waters (Jeju Island). The

88 identification was conducted by using molecular (DNA barcoding) and morphological

89 examination. The spiny lobsters used in this study were collected from the southern part of Jeju

90 Island, South Korea, where several branches of Kuroshio currents (Yellow Sea and Tsushima

91 warm currents) are reported to drift. Based on the newly recorded P. homarus homarus and $P$.

92 longipes as well as the new morphotype of P. japonicus discovered in this study, the list of spiny

93 lobster species and the general species diversity record within the South Korean waters was

94 updated. Thus, the findings of this study will facilitate appropriate regulation and management of

95 spiny lobsters in this area.

96

97 Materials \& Methods

98 Sample collection

99 This study was conducted under the approval of the animal care and use committee of Jeju

100 National University (No. 2020-0012). Adult spiny lobsters (Panulirus spp.) were collected from

101 three sampling sites along the southern coast of Jeju Island, South Korea. Site 1 was located

102 around Hwasun Harbor $\left(33^{\circ} 13^{\prime} 57.5^{\prime \prime} \mathrm{N} 126^{\circ} 19^{\prime} 55.8^{\prime \prime} \mathrm{E}\right)$, site 2 was around Seogwipo Harbor

$103\left(33^{\circ} 13^{\prime} 57.0^{\prime \prime} \mathrm{N} 126^{\circ} 33^{\prime} 53.2^{\prime \prime} \mathrm{E}\right)$, and site 3 was around Pyoseon Port $\left(33^{\circ} 19^{\prime} 37.2^{\prime \prime} \mathrm{N}\right.$

$104126^{\circ} 50^{\prime} 49.9^{\prime \prime}$ ) (Fig. 1). Spiny lobsters were located by scuba diving at night (8:00 to 11:00

105 p.m.) from August to November 2020 and caught using hand nets. The collected animals were

106 placed in iceboxes and transported to the Jeju Tropical Seawater Research Facility at the Jeju

107 Marine Research Center of the Korea Institute of Ocean Science and Technology, Jeju Island,

108 South Korea. All lobsters were reared in acrylonitrile butadiene styrene tanks (20 tons) with a 
109 constant circulation of seawater $\left(23 \pm 1{ }^{\circ} \mathrm{C}\right)$ and fed daily at 16:00 with commercially formulated

110 powder feed (Heukja, Kopec Ltd., Jeonla-Namdo, South Korea) until analysis.

112 Examination of morphological features

113 A total of 17 spiny lobsters were collected for morphological examination. The specimens were

114 anesthetized on ice for 10 min prior to the examination. Body length (BL) and weight (BW) of

115 each lobster were measured, and the detailed features of the body and appendages were

116 photographed for examination (Fig. 2). Morphological features and color markings were

117 examined with reference to the morphological characterization of lobsters described by George

118 and Holthuis (1965). Species identification was done based on the examination of body color,

119 presence of cross bands on antennal and antennular flagella, size and number of spines on the

120 antennular plate, availability of transverse grooves on abdominal segments, existence of

121 stridulating organs, and presence of exopods in the second and third maxillipeds.

122

123 DNA Extraction and PCR amplification

124 Genomic DNA was extracted from the muscle of the pereiopod of all 17 spiny lobsters. DNA

125 was extracted using the AccuPrep ${ }^{\circledR}$ Genomic DNA Extraction Kit (Bioneer, Daejeon, South

126 Korea), following the manufacturer's instructions. Concentration and purity of the extracted

127 DNA were measured using a Thermo Scientific ${ }^{\mathrm{TM}}$ NanoDrop ${ }^{\mathrm{TM}}$ One microvolume UV-Vis

128 spectrophotometer (Thermo Scientific, Wilmington, DE, USA).

129 A polymerase chain reaction (PCR) was performed to amplify the mitochondrial COI

130 gene region using the $\mathrm{HCO} 1490 / \mathrm{LCO} 2198$ universal primers, specially designed for

131 invertebrates (Folmer et al., 1994). PCR was performed using a $50 \mu \mathrm{L}$ reaction mixture, 
132 consisting of $100 \mathrm{ng}$ genomic DNA, $0.25 \mu \mathrm{L}$ Taq polymerase (Takara Bio Inc., Shiga, Japan), 5

$133 \mu \mathrm{L}$ 10X Ex. Taq DNA polymerase buffer (Takara Bio Inc.), $1 \mu \mathrm{L}$ each of $10 \mu \mathrm{M}$ forward and

134 reverse primers, and $4 \mu \mathrm{L}(2.5 \mathrm{mM}) \mathrm{dNTPs}$ (Takara Bio Inc.). The PCR thermal profile

135 comprised an initial step of $5 \mathrm{~min}$ at $94{ }^{\circ} \mathrm{C}$, followed by 30 cycles at $94{ }^{\circ} \mathrm{C}$ for $30 \mathrm{~s}, 50{ }^{\circ} \mathrm{C}$ for 30

$136 \mathrm{~s}$, and $72{ }^{\circ} \mathrm{C}$ for $45 \mathrm{~s}$, followed by a final extension at $72{ }^{\circ} \mathrm{C}$ for $5 \mathrm{~min}$. The amplified PCR

137 products were separated using $1 \%$ agarose gel electrophoresis, and target bands were purified

138 using the AccuPrep ${ }^{\circledR}$ PCR Purification Kit (Bioneer), according to the manufacturer's

139 instructions.

140

141 COI cloning and sequencing

142 Purified PCR products were ligated to the T-easy vector (Takara Bio Inc.). The ligation mixture

143 was prepared with $2 \mu \mathrm{L}$ ligation buffer, $3 \mu \mathrm{L}$ T-easy vector, $1 \mu \mathrm{L}$ T4 ligase, and $4 \mu \mathrm{L}$ PCR

144 water. Recombinant plasmids were transformed into Escherichia coli JM109 (DE3) (Promega,

145 USA), cultured on Luria-Bertani agar plates supplemented with ampicillin (LB amp+) and

146 incubated overnight at $37^{\circ} \mathrm{C}$. Subsequently, LB broth $(4 \mathrm{~mL})$ was inoculated with the grown

147 colonies and incubated overnight at $37^{\circ} \mathrm{C}$, following which plasmids were extracted using the

148 AccuPrep ${ }^{\circledR}$ plasmid extraction kit (Bioneer). Extracted plasmids were sent for sequencing at

149 Macrogen Pvt. Ltd. (South Korea).

150

151 Alignment and phylogenetic analysis

152 COI sequences were edited and aligned with the reference sequences of various spiny lobster

153 species, retrieved from the BOLD system (http://barcodinglife.org/) and the NCBI database

154 (https://www.ncbi.nlm.nih.gov/) using MEGA 7.0 (Kumar et al., 2016). Sequence alignment was 
155 generated using a high-throughput MUSCLE method (Edgar, 2004), and subsequent

156 phylogenetic analyses were performed using neighbor-joining (NJ), maximum likelihood (ML), 157 and Bayesian inference (BI) methods. NJ and ML were constructed using MEGA 7.0 (Kumar et

158 al., 2016) and RAxML v8.2.X (Stamatakis, 2014), respectively. Both the analyses were run with 1591000 bootstrap replications. In addition to ML, a priori test was performed using jModelTest

160 0.1.1(Posada, 2008) to determine the best evolutionary model fitted to the current sequences, and 161 the general time-reversible gamma distribution rate parameter $(\mathrm{GTR}+\mathrm{G})$ was used to construct

162 the tree (Guindon \& Gascuel, 2003; Posada, 2008). Finally, BI was performed for 5,000,000 163 generations using MrBayes 3.2.7a (Ronquist et al., 2012).

164 Additionally, pairwise mean distances between groups were calculated using MEGA 7.0 165 to obtain the genetic divergence information. Furthermore, DnaSP v5 (Librado \& Rozas, 2009) 166 was used to measure the nucleotide diversity and the number of polymorphic sites within each 167 clade to which the newly recorded Jeju Island spiny lobsters belonged.

168

169

170

171

172

173

174

175 bootstrap proportion of NJ and ML, followed by the posterior probability from BI analysis. Trees 176

177 to the ML tree, spiny lobsters collected from Jeju Island were grouped under four different 
178 clades: Clade A, Clade B, Clade C, and Clade D, which were monophyletic with Panulirus 179 japonicus, P. longipes, P. stimpsoni, and P. homarus, respectively (Fig. 3).

180 Clade A included eight COI sequences of spiny lobsters from Jeju Island, which were 181 closely related to P. japonicus from Japan and Taiwan. Of these, seven sequences were shown to 182 be exclusively claded with $P$. japonicus specimens collected from Japan, with a high bootstrap 183 proportion and posterior probability (NJ/ML/BI; 99/72/92) (Fig. 3). Meanwhile, only one 184 sequence was claded with the P. japonicus specimens collected from Taiwan (NJ/ML/BI; 99/77/99). Intraspecific diversity revealed that seven haplotypes were found exclusively from 186 187 188 189

Jeju Island with Pi value $5.0 \% \pm 2.0 \%$ and 59 polymorphic sites (Table 1).

Two COI sequences were included under Clade B. As shown in Figure 3, this clade was highly supported (NJ/ML/BI; 100/89/100) to be monophyletic with $P$. longipes as well as its subtypes, the $P$. longipes longipes and $P$. longipes fermorstriga. Specifically, the two spiny lobster sequences obtained in this study seemed to share a common ancestor, $P$. longipes from India (NJ/ML/BI; 67/67/100). However, the intraspecific diversity analysis indicated that both sequences differed slightly from each other, as indicated by the two haplotypes that were identified. The nucleotide diversity $(\mathrm{Pi} \pm \mathrm{SD})$ was $2.4 \% \pm 1.2 \%$ and five polymorphic sites were observed (Table 1).

Among the COI sequences of spiny lobsters collected in the current study, six sequences were clustered into clade C, which included P. stimpsoni from regions such as South China Sea and Hongkong. This clade was supported by 100/99 of NJ/ML bootstrap proportion and 100 posterior probability based on BI analysis (Fig. 3). In this study, four haplotypes of P. stimpsoni were found within Jeju Island. In addition, nucleotide diversity $(\mathrm{Pi} \pm \mathrm{SD})$ and number of polymorphic sites were reported at $2.4 \% \pm 1.2 \%$ and eight, respectively. 
In the current study, only one specimen was claded with the P. homarus group (Clade D).

202 The sequence of this specimen was closely related to the P. homarus homarus from Marquesas

203 Island, French Polynesia, and the topology was strongly supported by bootstrap proportions and

204 posterior probability (NJ/ML/BI; 100/100/100). These two sequences were distinct from the $P$.

205 homarus collected from Indonesia, Oman, India, Sri Lanka, Iran, and Mozambique. As for the

206 Jeju intraspecific variation, the analysis could not be performed due to the insufficient number of 207 samples.

208 The pairwise mean distances between clades were run using Tamura 3 software. The 209 closest genetic distance was between clade C (P. stimpsoni) and clade D (P. homarus), with $21025.3 \%$ differences. Meanwhile, the furthest distance was between clade A (P. japonicus) and 211 clade C (P. stimpsoni), with 41.7\% differences (Table 1).

212

213 Morphological examination

214 Material examined: P. japonicus (Jeju morphotype); Female; Total Length (TL): 28.5 cm; Body 215 Weight (BW): 551 g; Site 03, Pyoseon Port, Seogwipo, Jeju Island, South Korea; 33¹9’37.2”N, $216126^{\circ} 50^{\prime} 49.9^{\prime \prime} \mathrm{E}$; August 21, 2020; 10 m depth.

217

218 Description: The carapace is reddish brown in color, and abdominal segments are greenish 219 brown (Fig. 2A). White spots present in the lateral margin of the carapace and the lateral region 220 of the abdomen. Spines of various sizes are randomly scattered on the carapace, and majority of 221 the spine bases are black in color. The mid-dorsal surface of the carapace bears reddish-brown 222 hairs (Fig. 4A). The dorsal surface of the frontal horns is dark greenish-brown and white spots 223 are present. The ventral side of the frontal horn is orange. Frontal margin of the antennular plate 
224 armed with two separate medium-sized spines. The inner dorsal side of the antennal peduncles is

225 pinkish in color. The antennules are without cross bands. The ventrolateral margin of the

226 carapace made a reddish-brown soft surface line with white blotches (Fig. 4A). Non-interrupted

227 transverse grooves are visible on the dorsal surface of each abdominal segment (Fig. 5A).

228 Posteriorly directed hair is present in both the posterior margins of the somites and transverse

229 grooves. Transverse grooves are curved at the lateral end of the second, third, and fourth somites, 230 and interconnected with the corresponding pleural grooves in the first and third somites (Fig. 6A, 231 B). The transverse groove in the second somite ends up too close to its pleural groove, making a 232 pseudo connection. Both second and third maxillipeds bear exopods (Fig. 7A, B, C).

233

234 Material examined: P. japonicus (Holthuis morphotype); Female; Total Legnth (TL): 31cm;

235 Body Weight (BW): 1023 g; site 03, Pyoseon Port, Seogwipo, Jeju Island, South Korea;

$23633^{\circ} 19^{\prime} 37.2^{\prime \prime} \mathrm{N}, 126^{\circ} 50^{\prime} 49.9^{\prime \prime} \mathrm{E}$; August 21, 2020; 10 m depth.

237

238 Description: Base color of the carapace is reddish brown, and abdominal segments are greenish

239 brown. Lateral margin of the carapace and lateral region of the abdomen contain white spots.

240 Spines which are varying in sizes with black bases are scattered on the carapace. The mid-dorsal

241 surface of the carapace bears reddish-brown hairs (Fig. S1). Frontal horns are dark greenish

242 brown and white spots are present. Two separate medium size spines are present at the frontal

243 margin of the antennular plate. The antennules are without cross bands. Reddish brown soft

244 surface line margin the ventrolateral region of the carapace. White blotches are present on that

245 line. Each abdominal segment contain non-interrupted transverse groove with posteriorly

246 directed hairs on its posterior margin. Transverse grooves are curved at the lateral region of the 
247 second, third and fourth somites. There are no interconnections of transverse grooves with

248 corresponding pleural grooves in the second and third somites (Fig. S2). Both second and third 249 maxillipeds bear exopods.

250

251 Material examined: P. homarus homarus ; Female; TL: 37 cm; BW: 1390 g; Site 01, Hwasun

252 Harbor, Seogwipo, Jeju Island, South Korea; 3313'57.5"N, 126¹9'55.8"E; August 18, 2020; $253 \sim 10$ m depth

254

255 Description: The carapace and front part of the abdominal region are brownish to greenish in 256 color. Antennal and antennular peduncles, walking legs, posterior part of the abdominal region,

257 peduncles of the uropod, and base of the telson are greenish in color (Fig. 2B). The body consists 258 of numerous white spots, which are apparent in the posterior part of the abdomen. Both 259 antennular peduncles and antennular flagella contain white cross bands. The distal part of each 260 antennular peduncle contains white blotches. There are four well-separated spines on the 261 antennular plate and randomly scattered small spines between them. The horns are covered with 262 white spots, creating pseudo bands, and the frontal horn tips are orange (Fig. 4B). The post 263 cervical groove, lateral grooves, and the anterior margin of the carapace are blue. Furthermore,

264 the posterior margin of the antennular plate consists of a triangular design with blue and orange 265 colors. Additionally, non-interrupted transverse grooves are present in each abdominal segment, 266 and the anterior margin of the grooves form shallow scallops (Fig. 5B). The transverse grooves 267 form a crenulated articulation at the lateral area of every somite (Fig. 6C, D). A white spot is 268 present in the anterolateral region of each somite. The second maxilliped bears an exopod, while 269 it is absent in the third one (Fig. 7 D, 7E, 7F). 
271 Material examined: P. longipes ; Female; TL: 28 cm; BW: 667 g; Site 01, Hwasun Harbor,

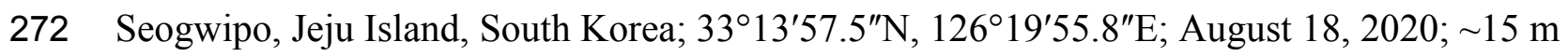

273 depth

274

275 Description: The body and the post-orbital area are brown, while the dorsal parts of the carapace 276 and anterior segments of the abdominal region are dark brown in color (Fig. 2C). Both carapace 277 and abdominal regions are covered with randomly scattered white and orange spots. The base of 278 the antennal peduncle is purple, and its dorsal inner side is pinkish brown. The frontal margin of 279 the antennular plate is armed with two separate small spines. Frontal horns are brown, while the 280 tips are orange, and there are two conspicuous medium-sized spines behind the frontal horns.

281 The carapace bears numerous spines of different sizes; some are black, while some have orange 282 tips with white bases (Fig. 4C). Antennular flagella are cross-banded in white. Legs bear orange 283 and white spots at the end of each segment. Orange lines on the lateral and ventral legs are 284 broken into irregular blotches. Transverse grooves are present in every abdominal segment and 285 connect laterally to the pleural grooves (Fig. 5C, Fig. 6E, F). Exopods are present in the second 286 and third maxillipeds (Fig. 7G, H, I).

Material examined: P. stimpsoni ; Female; TL: 28 cm; BW: 765 g; Site 02, Seogwipo Harbor,

289 Seogwipo, Jeju Island, South Korea; $33^{\circ} 13^{\prime} 57.0^{\prime \prime} \mathrm{N}, 126^{\circ} 33^{\prime} 53.2^{\prime \prime E}$; April 06, 2020; 15 m depth 290

291 Description: Body color is brown to olive green. The posterior part of the cervical groove on the 292 carapace is darker in color (Fig. 2D). Frontal horns are reddish brown in color, tips are pale 
293 yellow, and four cross lines of the same color are present. The lateral margin of the carapace

294 forms a white line, and another white line starting from the anterior part of the cervical groove

295 extends over it (Fig. 4D). The lateral region between these two lines is light orangish yellow. The

296 antennule plate is armed with four well-separated spines projected among the hairs, and the

297 frontal pair of spines is larger than that at the posterior region. Antennules are reddish brown

298 with white cross bands. The distal part of each antennule peduncle shows white blotches.

299 Pereiopods are reddish brown with longitudinal white lines and blotches in the propodus, carpus,

300 and merus. The abdominal segments are olive green in color. Reddish brown and pale-yellow

301 speckles are present in each segment. Transverse grooves are not present in any of the abdominal

302 segments. Instead, slight depressions associated with firm hairs are present in the middle of the

303 second, third, and fourth somites. These grooves were disturbed in the middle and became broad

304 on the lateral sides (Fig. 5D). A white spot was present at the top-notch of the triangular plate in

305 the first somite. The same conspicuous white spots are present in the anterolateral region of each

306 somite, except in the second somite, where it is present as a posteriorly interrupted white line

307 (Fig. 6G, F). The posterior margin of each pleuron bears four conspicuous teeth associated with

308 hairs, arranged in descending order of size. The second maxilliped bears an exopod, but the third 309 maxilliped does not (Fig. 7J, K, L).

310 The major comparative morphological features used for the identification of spiny

311 lobsters are shown in Table 2.

312

\section{Discussion}

314 This study was conducted to update the records of spiny lobster species in South Korean waters,

315 based on the specimen collection in Jeju Island. A previous study identified four spiny lobster 
316 species from the genus Panulirus sporadically distributed in South Korean waters: P. japonicus,

317 P. penicilatus, $P$. stimpsoni, and P. versicolor. However, only P. stimpsoni has been reported in

318 Jeju Island waters (Kim et al., 2009).

319 In the current study, spiny lobsters were identified using DNA barcoding and

320 morphological analysis. A maximum likelihood tree of COI marker was constructed by including

321 the spiny lobster sequences available in the Genbank and the BOLD system. The results

322 confirmed that the spiny lobsters collected in this study belong to clade A, B, C, and D, which

323 are reciprocally monophyletic with $P$. japonicus, $P$. longipes, $P$. stimpsoni, and $P$. homarus,

324 respectively. Among the four clades, the closest genetic distance was observed between intra

325 Jeju Island specific spiny lobsters from clade C (P. stimpsoni) and D (P. homarus). On the other

326 hand, the furthest distance was found between clade A (P. japonicus) and C (P. stimpsoni).

327 These results provided additional evidence supporting the previous studies which state that spiny

328 lobsters (Genus: Panulirus) can be morphologically and phylogenetically diversified into two

329 major lineages (Ptacek et al., 2001; George, 2005).

330

Intraspecific Jeju diversity analysis revealed that clade A appears to have the highest

331 divergence rate based on the number of haplotypes, nucleotide diversity $(\mathrm{Pi})$ and polymorphic

332 sites. Notably, among the collected specimens, majority of the sequences were observed in this

333 clade and thus, were genetically identified as P. japonicus. Among these sequences, one

334 sequence was exclusively sub-claded with $P$. japonicus from Taiwan, while the remaining were

335 sub-claded with those from Japan. Therefore, it can be assumed that the P. japonicus specimens

336 found in Jeju Island originated from the same population source as those from Japan and Taiwan.

337 Our findings were consistent with those of previous studies, which state that P. japonicus across

338 populations within the Japan, Taiwan, and southern Chinese waters have originated from the 
339 same larval pool that mixed within the Kuroshio counter-current region (Inoue et al., 2007;

340 Chan, Yang \& Wakabayashi, 2019). Furthermore, this research partially supported the previous

341 hypothesis regarding non-existence of sub-divisions in the P. japonicus population within its

342 spatial distribution (Chan et al., 2019).

343 Despite the monophyletic lineages, two morphotypes of $P$. japonicus were found in the

344 current study, which will be addressed as original type (George \& Holthuis, 1965) and Jeju type.

345 Four of the eight $P$. japonicus specimens found in the current study appeared to be Jeju type

346 based on the variations observed in its morphological features compared to the original type

347 (George \& Holthuis, 1965; Kim et al., 2009). The Jeju type specimens had a connected pleural

348 and transverse groove at the third abdominal somite, unlike the holotype from Japan (George \&

349 Holthuis, 1965). Moreover, the transverse groove ends close to the pleural groove in the second

350 abdominal somite, forming a pseudo connection, which creates a noticeable gap in the previously

351 described specimens. Morphological variations in spiny lobsters have been discovered in the

352 species $P$. homarus and $P$. longipes (Sekiguchi, 1991; Lavery et al., 2014). In addition to this, the

353 evolutionary divergence and phenotypic adaptation that results from geographical dispersal were

354 shown in the different colorations and abdominal patterns among $P$. homarus morphotypes

355 observed in this study. The phylogenetic clusters clearly supported these apparent variations

356 based on population; thus, each was introduced as a different subspecies (Lavery et al., 2014). In

357 the case of P. japonicus from Jeju Island, each morphotype does not indicate a distinct genetic

358 cluster or an intra spatial subdivision. It is likely that the Jeju type variation occurred as part of

359 an adaptive response due to selective forces and/or environmental restrictions during

360 developmental and settlement stages (George, 2005; Vieira et al., 2016). 
This study confirmed that the Jeju Island spiny lobsters in clade B were $P$. longipes,

362

363

364

365

366

367

368

369

370

371

372

373

374

375

376

377

378

379

380

381

382

383

based on morphological and phylogenetic species concepts (George \& Holthuis, 1965; Ravago \&

Juinio, 2002). The intraspecific diversity of mtDNA COI revealed that, unlike its sister clade

(clade A), clade B had a relatively low divergence based on its Pi value and polymorphic sites. In

the genus Panulirus, P. longipes is one of the two spiny lobsters that have subspecies because of

its morphotype variations (George \& Holthuis, 1965). Around the East China Sea region, the subspecies $P$. longipes longipes and $P$. longipes femoristriga are distributed throughout

southwestern Japan, including Okinawa and Yaeyama Island, through the northern side of

Taiwan (Sekiguchi, 1991). The discovery of P. longipes in Jeju Island has updated the records of spiny lobsters inhabiting South Korean waters in general.

In clade $\mathrm{C}$, six spiny lobsters had a well-supported monophyletic relation with $P$.

stimpsoni from Hong Kong and the South China Sea. Compared to the other spiny lobsters in the current study, the phylogenetic analysis of $P$. stimpsoni remains understudied. This might partially be due to the limited distribution of this species within the East and the South China Sea (Holthuis, 1991; Liu \& Cui, 2011). However, a previous phylogenetic study based on genomic sequences of this species confirmed that the lineage of $P$. stimpsoni among the Decapoda is monophyletic with $P$. japonicus under the Palinura clade, which is closest to the infraorder Astacidea (Liu \& Cui, 2011).

In agreement with the COI result, morphological characterization of the specimen from clade D confirmed that it was identical to the P. stimpsoni holotype from Hong Kong (Holthuis, 1991). The presence of this species in South Korean waters has also been reported in the southern part of Jeju Island (Kim et al., 2009). Morphologically, some features were remarkably similar to those of $P$. versicolor. However, a feature in $P$. versicolor, such as a distinct 
384 continuous white transverse band along the edge of its first to sixth abdominal somite posteriors,

385 is the key to differentiate between these two species (Holthuis, 1991; Kim et al., 2009).

386

As reported previously, the current study also showed that a divergent monophyletic

387

pattern could be observed within the subspecies of $P$. homarus (Lavery et al., 2014; Singh et al.,

2017). A spiny lobster found in Jeju Island waters appeared to be closely related to the

subspecies P. homarus homarus in Marquesas Island, French Polynesia (Ptacek et al., 2001).

390

This finding is worth further discussion with adequate number of samples. Although the

morphological features of Jeju Island P. homarus were identical to those described by George

392

and Holthuis (1965), in concordance to its COI sequence, this specimen was further confirmed to

belong to the Homarus morphotypes based on its dark green coloration and the presence of

microsculpta (Berry, 1974; Holthuis, 1991). This corroboration of $P$. homarus has updated the

list of spiny lobster species inhabiting the South Korean coastal region.

396

397

\section{Conclusions}

398 This study aimed to identify the spiny lobsters found in Jeju Island by using a phylogenetic and

morphological approach. Based on the results of this study, it can be concluded that the use of

400 DNA barcoding technique along with morphological examination could enhance clarity

401 regarding the evolutionary and taxonomical position of spiny lobsters from Jeju Island among

402 those from different population regions. In this regard, two of the four spiny lobster species

403 identified in this study, $P$. longipes and $P$. homarus homarus were recorded for the first time in

404 South Korean waters. In addition, morphological variations discovered in the Jeju type $P$.

405 japonicus seem to be the first records within $P$. japonicus taxonomical studies. As the record has

406 been updated, the results of this study could aid in updating the global conservation status of

407 spiny lobsters. However, further phylogeography and population genetic studies are necessary 
408 for better understanding their evolutionary and diversity status. This study implied that 409 considerable biodiversity remains undiscovered in South Korea, and DNA barcoding could be a 410 potential tool for unraveling the biodiversity.

411

\section{Acknowledgements}

413 Authors are thankful to Dr. Chulhong Oh, Ms. Moonjeong Lee and Dr. Soojin Heo of the Korea 414 Institute of Ocean Science and Technology (KIOST) for their expert assistance and helpful 415 suggestions.

416

\section{References}

418 Berry PF. 1974. A Revision of the Panulirus Homarus-Group of Spiny Lobsters (Decapoda, 419 Palinuridae). Crustaceana 27:31-42a. DOI: 10.1163/156854074X00208.

420 Biodiversity Division, Nature Conservation Bureau, Ministry of Environment R of K. 2014. The Fifth National Report to the Convention on Biological Diversity Republic of Korea. :1-89.

422

423

424

425

426

427

428

429

430

431

Bucklin A, Steinke D, Blanco-Bercial L. 2011. DNA Barcoding of Marine Metazoa. Annual Review of Marine Science 3:471-508. DOI: 10.1146/annurev-marine-120308-080950.

Chan TY, Yang CH, Wakabayashi K. 2019. Amended larval recruitment model for the Japanese spiny lobster Panulirus japonicus based on new larval records and population genetic data in Taiwan. Journal of Oceanography 75:273-282. DOI: 10.1007/s10872-018-0498-5.

Edgar RC. 2004. MUSCLE: Multiple sequence alignment with high accuracy and high throughput. Nucleic Acids Res 32:1792-1797. DOI: 10.1093/nar/gkh340.

Farhadi A, Jeffs AG, Farahmand H, Rejiniemon TS, Smith G, Lavery SD. 2017. Mechanisms of peripheral phylogeographic divergence in the indo-Pacific: Lessons from the spiny lobster Panulirus homarus. BMC Evolutionary Biology 17:195. DOI: 10.1186/s12862-017-1050-8. 
432 Folmer O, Black M, Hoeh W, Lutz R, Vrijenhoek R. 1994. DNA primers for amplification of 433 mitochondrial cytochrome c oxidase subunit I from diverse metazoan invertebrates. $434 \quad$ Molecular marine biology and biotechnology. DOI: 10.1071/ZO9660275.

435 George RW. 2005. Review: Evolution of life cycles, including migration, in spiny lobsters 436 (Palinuridae). New Zealand Journal of Marine and Freshwater Research 39:503-514. DOI: 10.1080/00288330.2005.9517329.

438

George R, Holthuis L. 1965. A revision of the Indo-West Pacific spiny lobsters of the Panulirus japonicus group. Zoologische verhandelingen 72. DOI: 10.1016/0011-7471(76)91212-2.

440 Guindon S, Gascuel O. 2003. A Simple, Fast, and Accurate Algorithm to Estimate Large 441 Phylogenies by Maximum Likelihood. Systematic Biology 52:696-704. DOI: $10.1080 / 10635150390235520$.

443 Holthuis L. 1991. FAO species catalogue. Vol.13. Marine Lobsters of the World. An annotated 444 and illustrated catalogue of marine lobsters known to date.

445 Inoue N, Watanabe H, Kojima S, Sekiguchi H. 2007. Population structure of Japanese spiny lobster Panulirus japonicus inferred by nucleotide sequence analysis of mitochondrial COI gene. Fisheries Science 2007 73:3 73:550-556. DOI: 10.1111/J.1444-2906.2007.01367.X.

Kim JK. 2009. Diversity and Conservation of Korean Marine Fishes. Korean Journal of $449 \quad$ Ichthyology 21:52-62.

450 Kim JN, Choi JH, Oh TY, Kim ST, Cha HK, Chang DS. 2009. Two Spiny Lobsters of the Genus 451 Panulirus (Crustacea: Decapoda: Palinuridae) from Korean Waters. Fisheries and aquatic 452 sciences 12:339-341. DOI: 10.5657/fas.2009.12.4.339. 
453 Kumar S, Stecher G, Tamura K, Dudley J. 2016. MEGA7: Molecular Evolutionary Genetics 454 Analysis Version 7.0 for Bigger Datasets Downloaded from. Mol. Biol. Evol 33:1870455 1874. DOI: $10.1093 / \mathrm{molbev} / \mathrm{msw} 054$.

456 Lavery SD, Farhadi A, Farahmand H, Chan TY, Azhdehakoshpour A, Thakur V, Jeffs AG. 2014. 457 Evolutionary Divergence of Geographic Subspecies within the Scalloped Spiny Lobster 458 Panulirus homarus (Linnaeus 1758). PLoS ONE 9:e97247. DOI: 10.1371/journal.pone.0097247.

460 Leray M, Knowlton N. 2016. Censusing marine eukaryotic diversity in the twenty-first century. 461 Philosophical Transactions of the Royal Society B: Biological Sciences 371:20150331. 462 DOI: $10.1098 /$ rstb.2015.0331.

463 Librado P, Rozas J. 2009. DnaSP v5: a software for comprehensive analysis of DNA 464 polymorphism data. Bioinformatics (Oxford, England) 25:1451-2. DOI: $465 \quad$ 10.1093/bioinformatics/btp187.

466 Liu Y, Cui Z. 2011. Complete mitochondrial genome of the Chinese spiny lobster Panulirus 467 stimpsoni (Crustacea: Decapoda): genome characterization and phylogenetic 468 considerations. Molecular Biology Reports 38:403-410. DOI: 10.1007/s11033-010-0122-2. 469 Meyer CP, Paulay G. 2005. DNA barcoding: error rates based on comprehensive sampling. $470 \quad$ PLoS biology 3:e422. DOI: 10.1371/journal.pbio.0030422.

471 Park JM, Huh SH. 2018. Epibenthic invertebrate fauna in the southern coast of the East Sea, $472 \quad$ Korea. Journal of Asia-Pacific Biodiversity 11:217-222. DOI:

$473 \quad$ 10.1016/J.JAPB.2018.03.006.

474 Posada D. 2008. jModelTest: phylogenetic model averaging. Molecular biology and evolution 475 25:1253-6. DOI: 10.1093/molbev/msn083. 
476 Ptacek MB, Sarver SK, Childress MJ, Herrnkind WF. 2001. Molecular phylogeny of the spiny 477 lobster genus panulirus (Decapoda: Palinuridae). Marine and Freshwater Research

478 52:1037-1047. DOI: 10.1071/MF01070.

479

480

481

482

483

484

485

486

487

488

489

490

491

492

493

494

495

496

Ravago RG, Juinio MA. 2002. Phylogenetic Position of the Striped-Legged Forms of Panulirus longipes (A. Milne-Edwards, 1868) (Decapoda, Palinuridae) Inferred from Mitochondrial DNA Sequences. Crustaceana 75:1047-1059.

Ronquist F, Huelsenbeck J, Teslenko M. 2011. MrBayes Version 3.2 Manual: Tutorials and Model Summaries. Manual MrBayes:1-103.

Sekiguchi H. 1991. Two Forms of Panulirus longipes femoristriga (Crustacea, Palinuridae) from Ogasawara Waters, Japan.

Sembiring A, Pertiwi NPD, Mahardini A, Wulandari R, Kurniasih EM, Kuncoro AW, Cahyani NKD, Anggoro AW, Ulfa M, Madduppa H, Carpenter KE, Barber PH, Mahardika GN. 2015. DNA barcoding reveals targeted fisheries for endangered sharks in Indonesia. Fisheries Research 164:130-134. DOI: 10.1016/j.fishres.2014.11.003.

Senevirathna JDM, Munasinghe DHN. 2013. Identification of taxonomic status of spiny lobster species in Sri Lanka Using DNA barcoding and its implications on fisheries and conservation programs. Tropical Agricultural Research 25:96. DOI: 10.4038/tar.v25i1.8033.

Singh SP, Groeneveld JC, Al-Marzouqi A, Willows-Munro S. 2017. A molecular phylogeny of the spiny lobster Panulirus homarus highlights a separately evolving lineage from the Southwest Indian Ocean. PeerJ 5:e3356. DOI: 10.7717/peerj.3356. 
497 Stamatakis A. 2014. RAxML version 8: a tool for phylogenetic analysis and post-analysis of 498 large phylogenies. Bioinformatics (Oxford, England) 30:1312-3. DOI:

$499 \quad$ 10.1093/bioinformatics/btu033.

500 Vieira AR, Sofia A, Rodrigues B, Sequeira V, Neves A, Paiva RB, Vio O, Paulo S, Serrano 501 Gordo L. 2016. Genetic and Morphological Variation of the Forkbeard, Phycis phycis 502 (Pisces, Phycidae): Evidence of Panmixia and Recent Population Expansion along Its 503 Distribution Area. DOI: 10.1371/journal.pone.0167045.

504

505 
Figure 1

Map showing the sampling sites of spiny lobsters collected by scuba diving along the southern coast line of the Jeju Island.

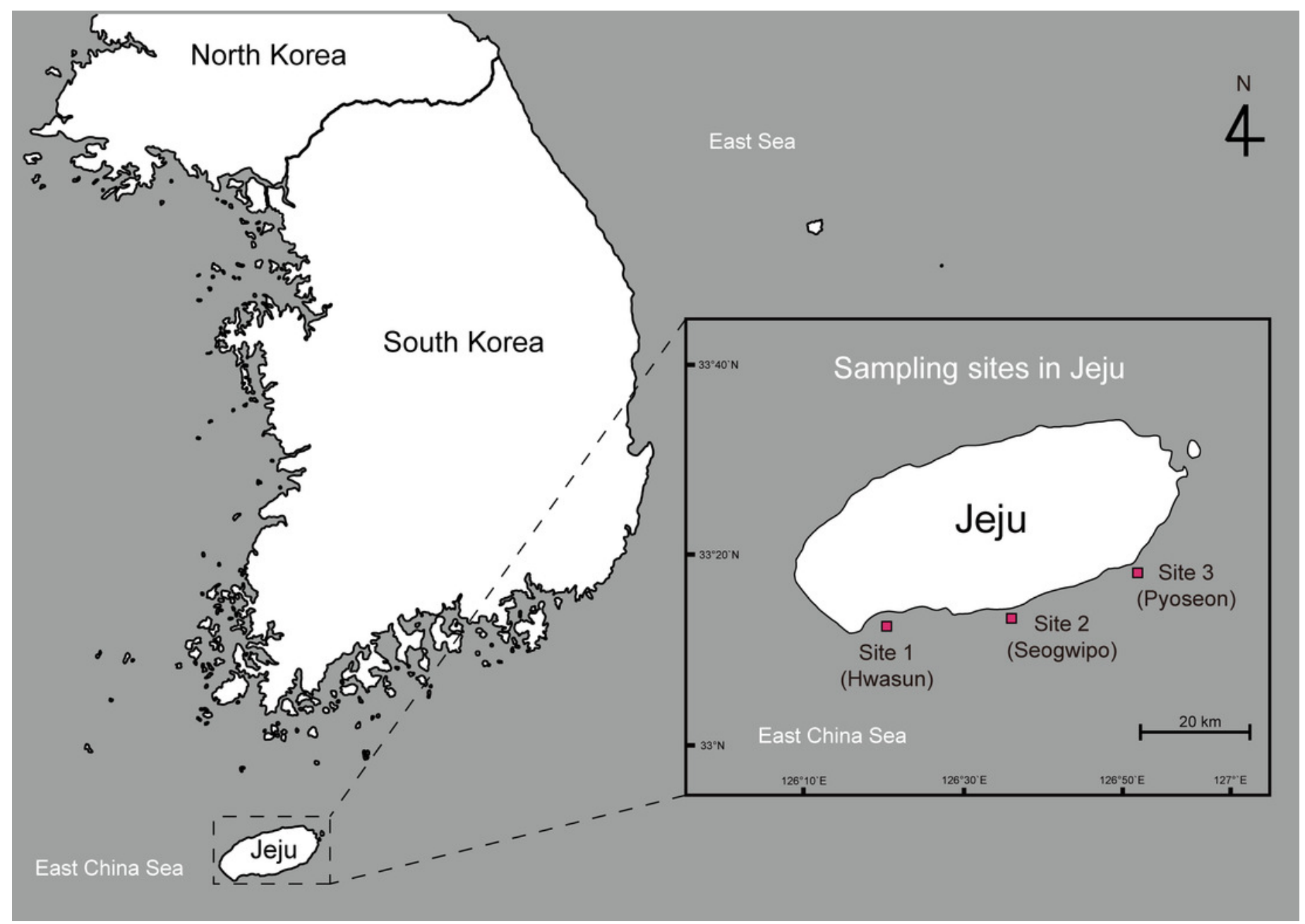




\section{Figure 2}

Photographs of dorsal and ventral side of spiny lobster specimens collected from Jeju Islad, South Korea. (A) P. japonicus, (B) P. homarus homarus, (C) P. longipes, and (D) P. stimpsoni..

(A) P. japonicus, (B) P. homarus homarus, (C) P. longipes, and (D) P. stimpsoni.

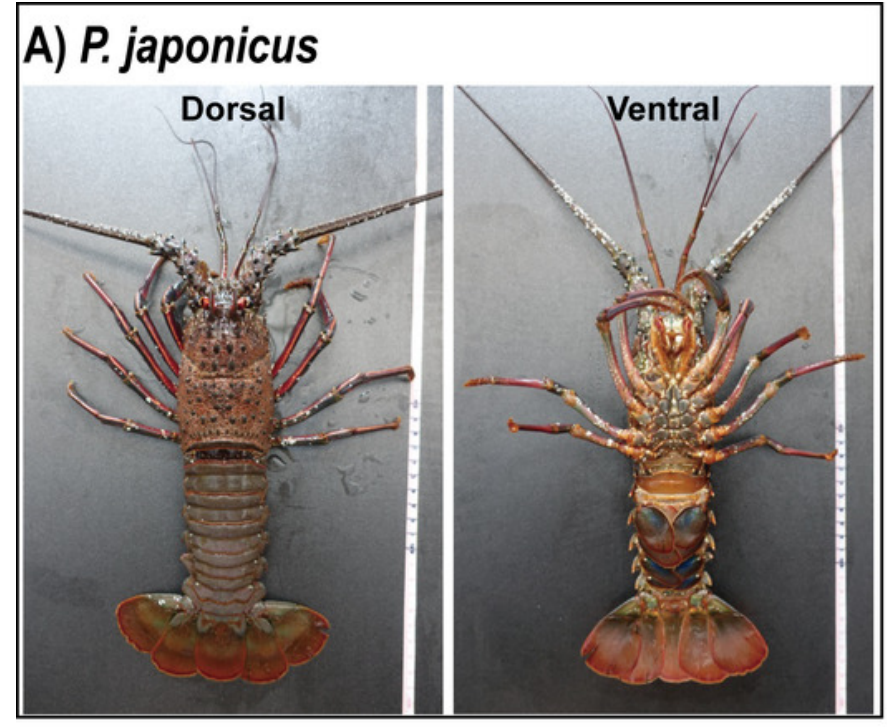

\section{C) P. longpes}

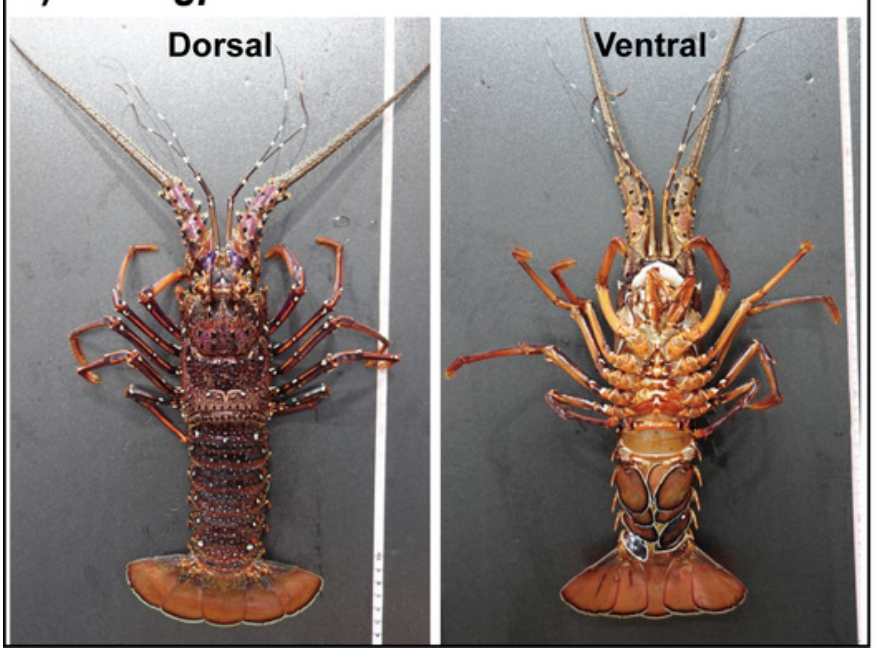

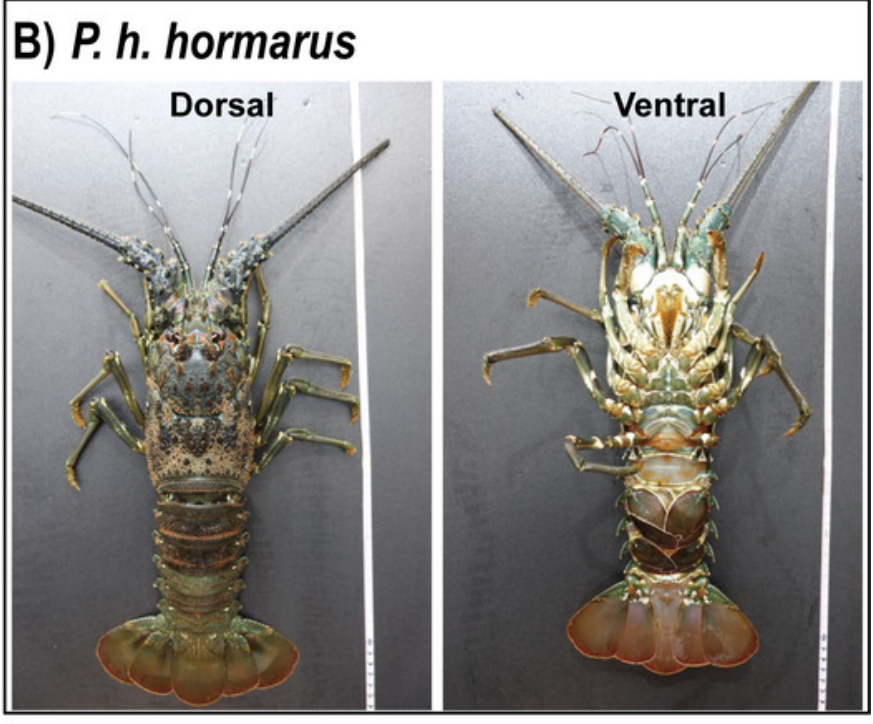

\section{D) P. stimpsoni}

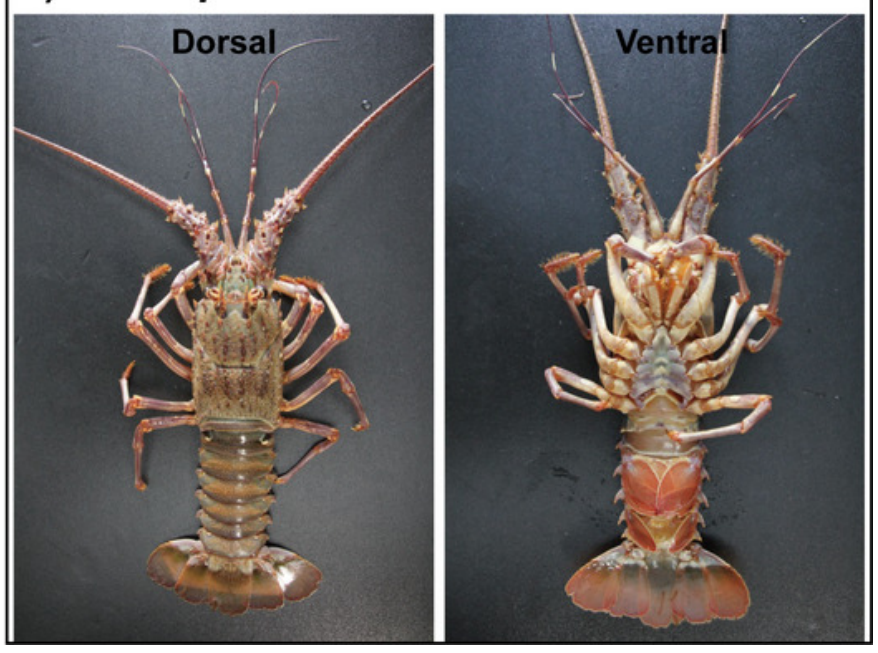




\section{Figure 3}

Maximum likelihood constructed tree of spiny lobster COI mitochondrial DNA.

The branch values indicate bootstrap proportion of neighbor joining and maximum likelihood followed by posterior probability of Bayesian inference analysis, respectively (maximum proportion is equal to 100). Scale bar represents the number of base substitutions per site. 


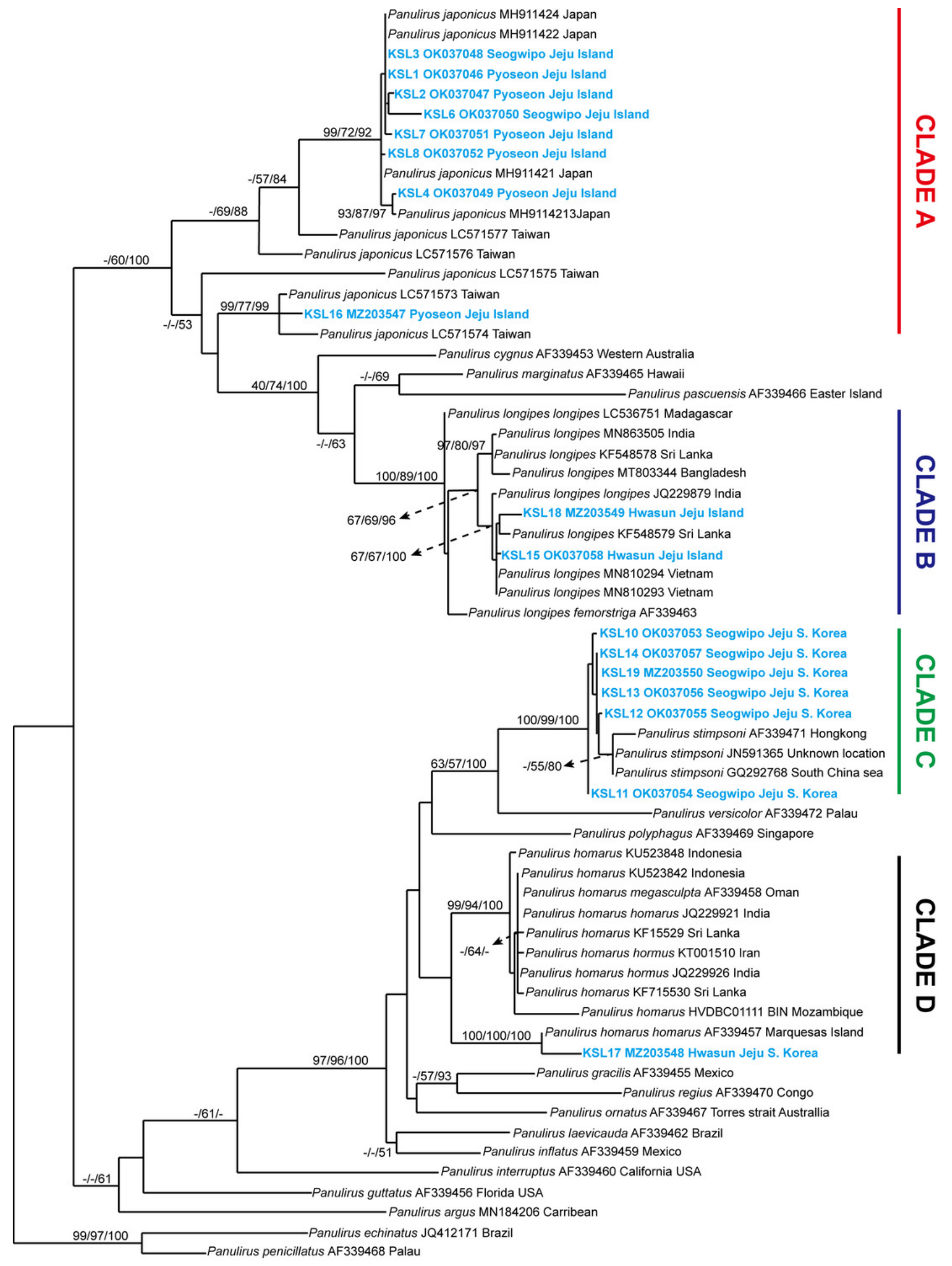




\section{Figure 4}

Photographs of lateral side of the carapace of spiny lobsters collected from Jeju Island, South Korea.

Arrow numbers of each photograph indicate the following morphological features respectively; A) P. japonicus, fh: Dark greenish brown frontal horns with white spots and orange color ventral margin; s: Randomely scattered spines on carapace with black color basal area; IM: White spotted lateral margin of the carapace; Enlarged area demarcated by rectangle: Reddish brown hairs on the mid-dorsal area of the carapace. B) P. homarus homarus, fh: Frontal horns covered with white spots which create pseudo cross-bands; Ig: Blue color lateral groove; aps: Conspicuous spines on antennular plate; s: Spines with white color basal area in lateral region of the carapace; Enlarged area demarcated by rectangle: Brownish yellow stiff hairs around the base of the spinules on posterior-lateral area of the carapace. C) P. longipes, fh: Brown color frontal horns with orange color tips; ms:

Conspicuous two medium size spines stand behind the frontal horns; bs: Black color spine; s: Spine with orange color tip and white color base; Enlarged area demarcated by rectangle: Reddish brown hairs on posterior mid dorsal area of the carapace. D) P. stimpsoni, fh: Reddish brown frontal horns with four pale yellow cross-bands; ss: Two small size conspicuous spines behind the frontal horns; s: Brown tipped small spine on carapace; IM: White lateral margin of the carapace; wl: White line over the lateral margin of the carapace; Enlarged area demarcated by rectangle: Pale yellow color hairs on the mid-dorsal area of the carapace. fh: frontal horns; s:spine; Im: lateral margin; aps: antennular plate spine; Ig: lateral groove; ms: medium size spine; ss: small size spine; wl: white line 

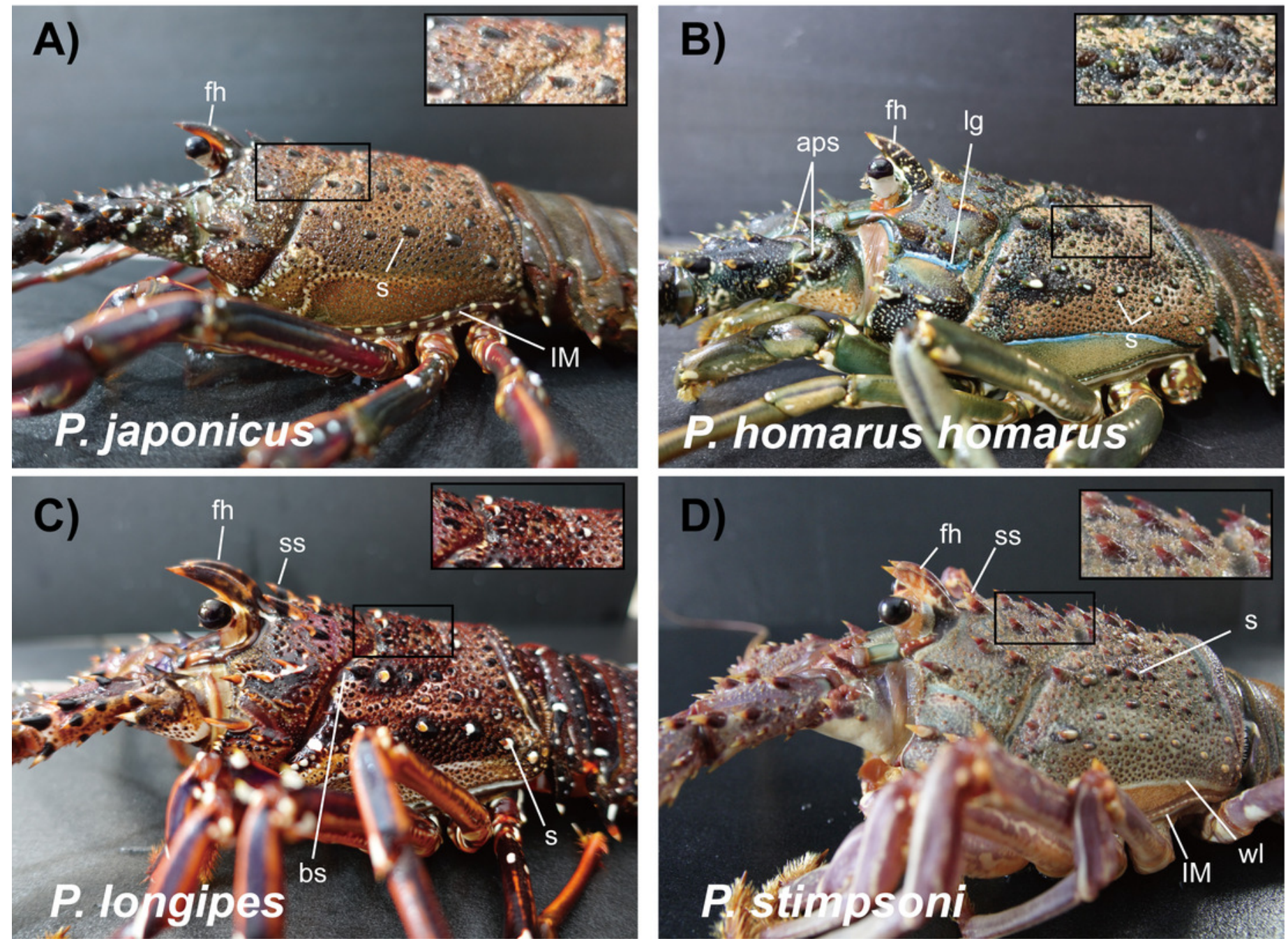


\section{Figure 5}

Photographs of dorsal side of the abdomen somites of spiny lobsters collected from Jeju Island, south Korea.

Arrow numbers of each photograph indicate the following morphological features respectively; A) P. japonicus a: Non-interrupted transverse groove with posteriorly directed hairs; b: Posterior margin of the second somite with posteriorly directed hairs; c: Brown to purplish color base of telson; d: Reddish brown and slightly curved posterior margin of telson. B) P. homarus homarus a: Shallow scallops in anterior margin of the transverse groove; $b$ : Posterior margin of the second somite; c: Numerous white spots in posterior somites; $d$ : Greenish brown and rounded posterior margin of telson. C) P. longipes a: Non-interrupted transverse groove with posteriorly directed hairs; b: Posterior margin of the second somite with hairs; c: Median notched of transverse grooves in second, third and fourth somites; $d$ : Numerous white and orange color spots in distal part of the abdomen; e: Dark brown line followed by white line in posterior margin of the telson. D) P. stimpsoni a: Stiff hairs on dorsal surface of the abdomen somite; $b$ : Disturbed pattern of hair and slight depression in middorsal region of the second,third and fourth somites; c: Reddish brown and pale yellow color spots in posterior part of the abdomen; $d$ : Reddish brown line followed by white line at the rounded posterior margin of the telson. 

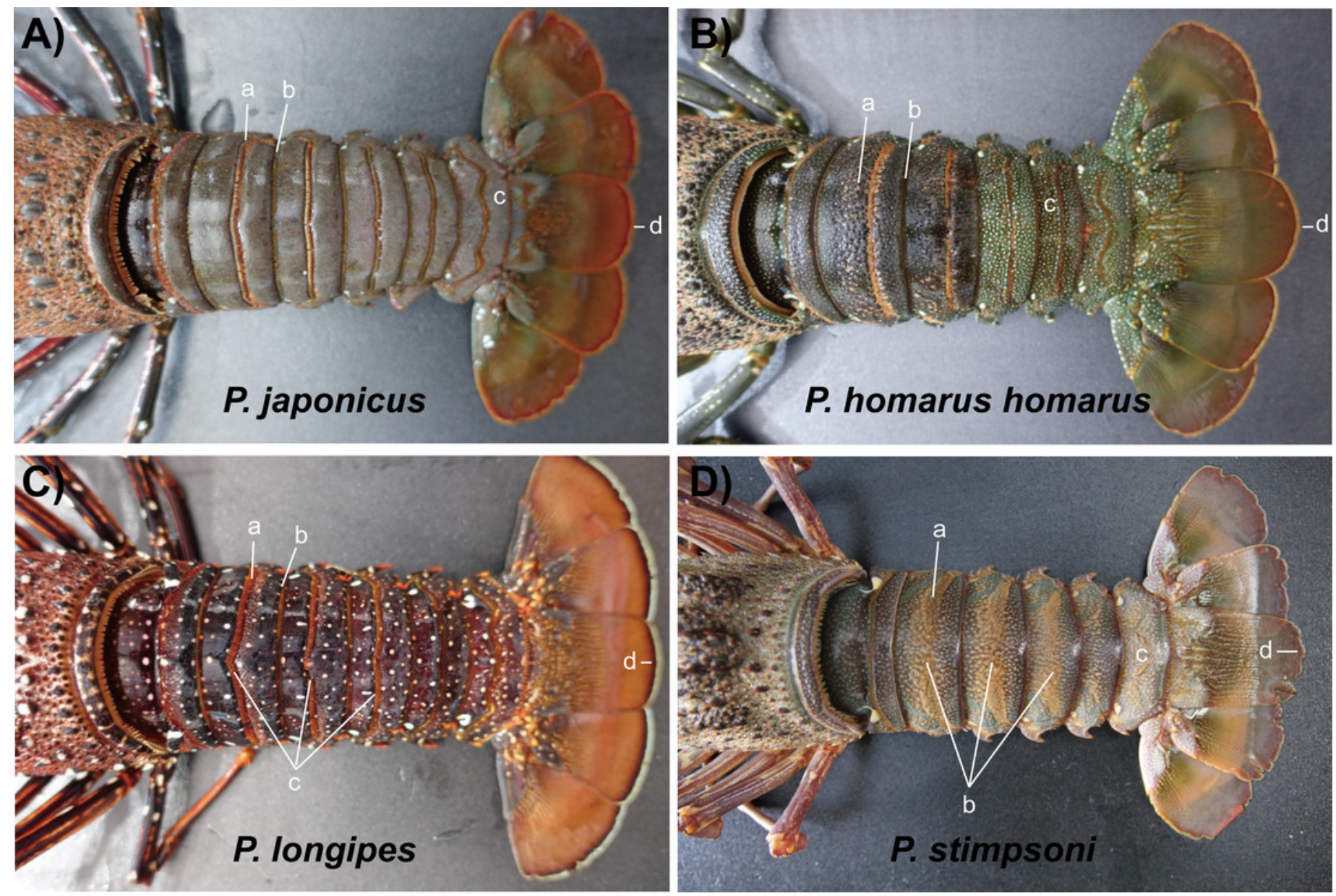


\section{Figure 6}

Photographs of lateral side of the abdominal somites of spiny lobsters collected from Jeju Island, South Korea and their diagrammatic view.

Arrows with the lowercase lettera of each photograph indicate the following morphological features respectively; A, B) P. japonicus a: Posteriorly directed hairs in transverse groove; $b$ : Posteriorly directed hairs in posterior margin of the second somite; c: Curved transverse groove at the lateral end of second,third and fourth somites; $d$ : Interconnection between transverse groove and pleural groove at first somite; e: Interconnection between transverse groove and pleural groove at third somite; f: Transverse groove is ending up very close to pleural groove of second somite. C, D) P. homarus homarus a: Shallow scallops on anterior margin of the transverse groove; $b$ : Crenulated articulation at lateral end of the transverse groove; c: White spot in anterior-lateral region of fourth somite (present in each somite except first); d: Numerus white spots on posterior somites. E, F) P. longipes a: Short stiff hairs on transverse groove in first somite; b: Posteriorly directed hairs in transverse groove; c: Posteriorly directed hairs in posterior margin of the somite; $d$ : Tubercles in anterior margin of the pleuron of somite II; e: White spot in the anterior-lateral region of the fourth somite (present in each somite); f: Conspicuous white spot on pleuron (present in all pleura except first). G, H) P. stimpsoni a: Slight depressions and associated firm hairs on dorsal side of the second, third and fourth somites; b: White spot in anteriolateral region of the fourth somite (present in each somite except first); c: Four conspicuous teeth (descending order in size) in posterior margin of the pleuron with hairs. 

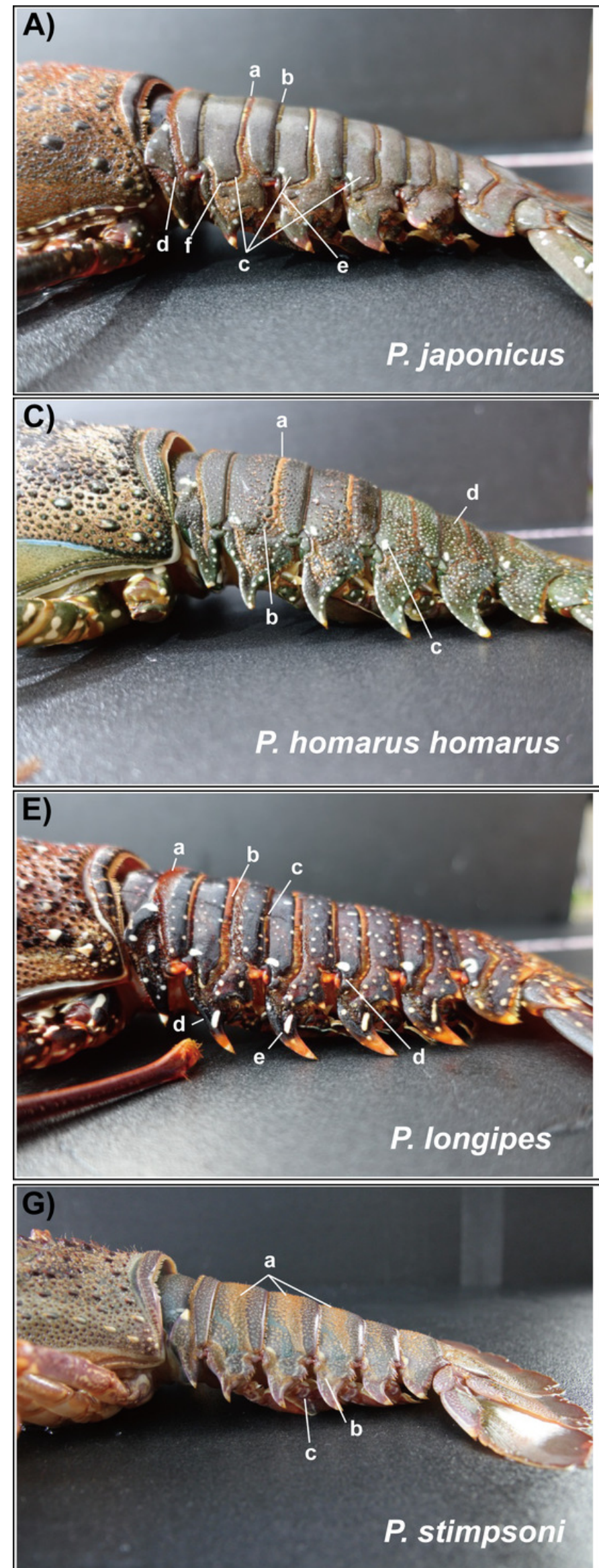

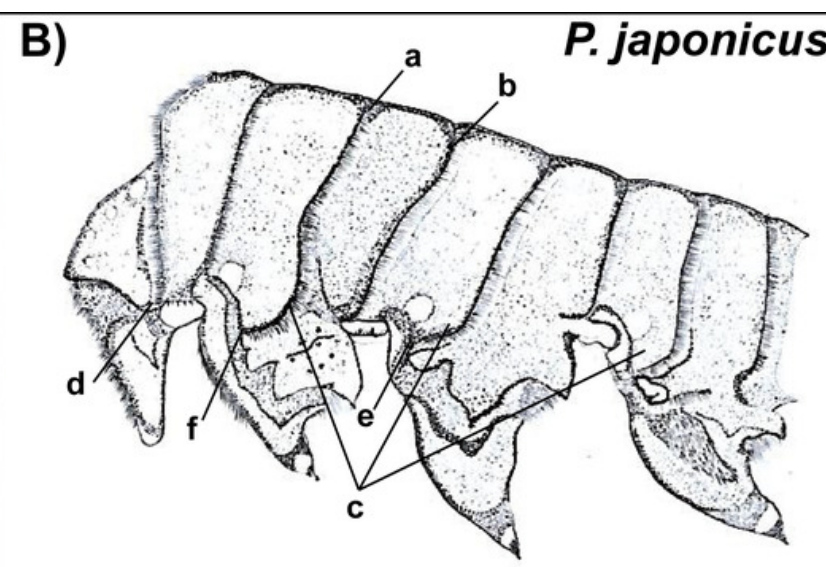

P. homarus homarus

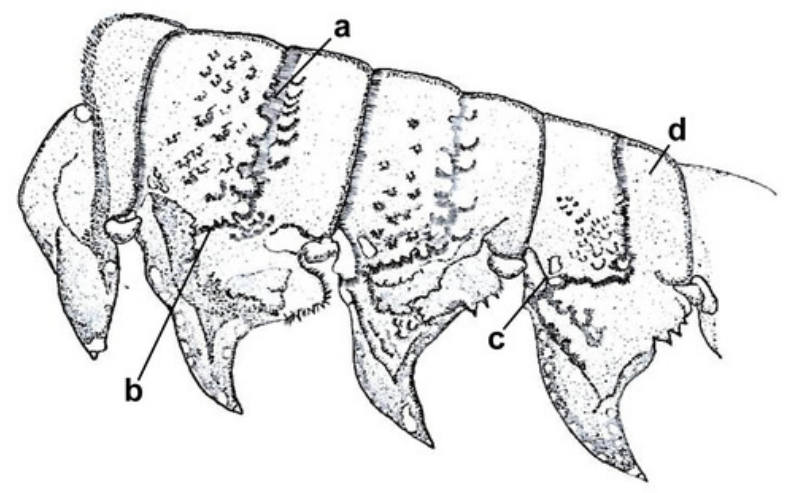

F)
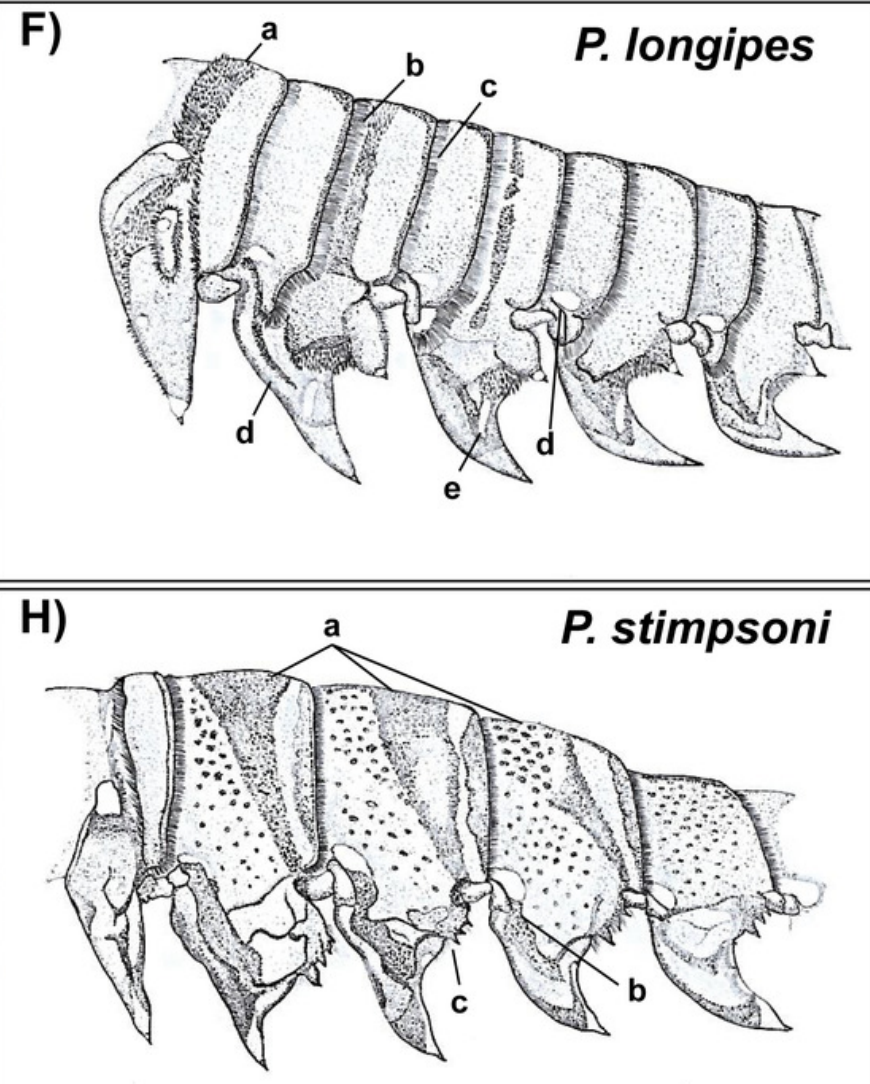


\section{Figure 7}

Photographs and diagrammatic views of the distinguished mouth parts of four spiny lobster species.

(A) Photograph of mouth region, (B) second maxilliped, (C) third maxilliped of $P$. japonicus ; (D) Photograph of mouth region, (E) second maxilliped, (F) third maxilliped of $P$. homarus homarus; $(\mathrm{G})$ Photograph of mouth region, $(\mathrm{H})$ second maxilliped, (I) third maxilliped of $P$. longipes; (J) Photograph of mouth region, (K) second maxilliped, (L) third maxilliped of $P$. stimpsoni. b, basis; $c$, carpus; d, dactyl; ex, exopod; fm, first maxilliped; i, ishium; m, merus; p, propodus; sm, second maxilliped; tm, third maxilliped. Scale bars represent $1 \mathrm{~cm}$. 

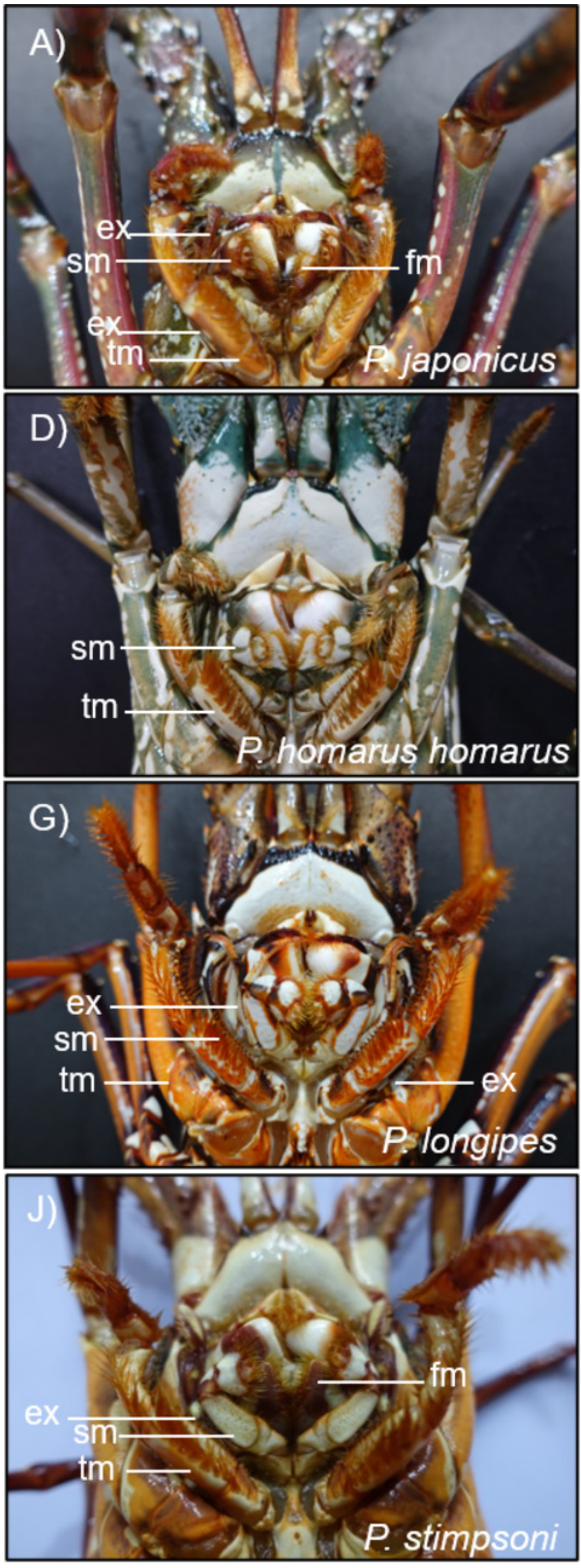

B)

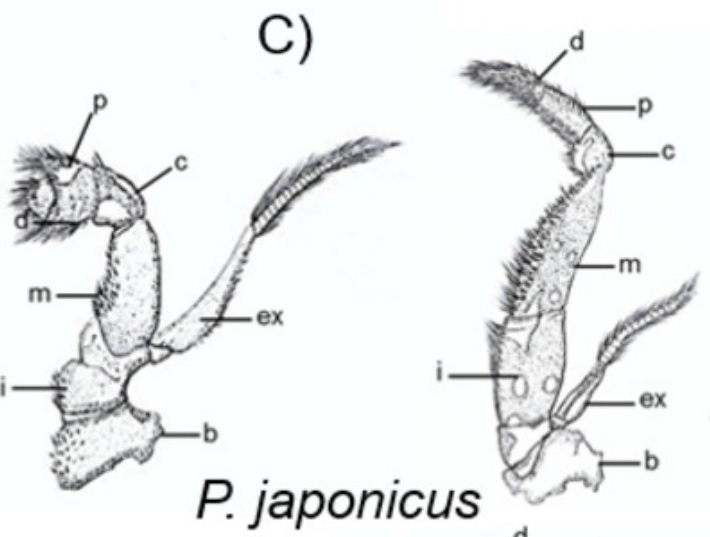

E)

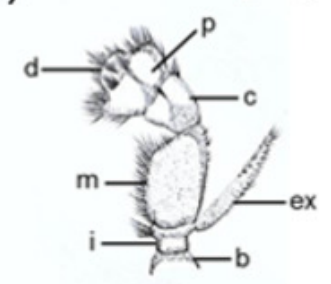

F)

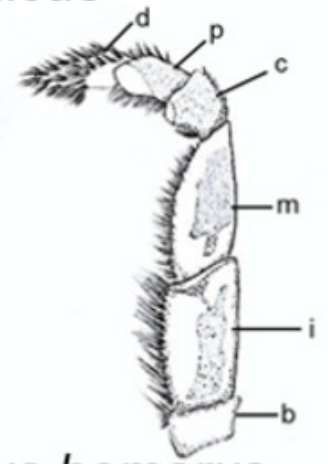

$P$. homarus homarus

H)

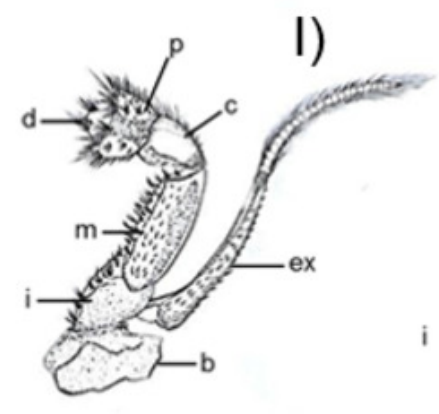

\section{P. longipes}

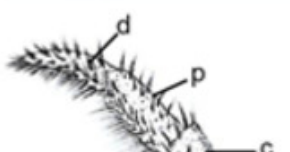

K)

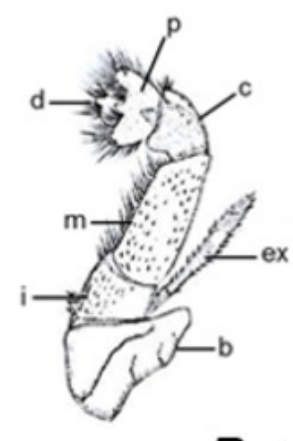

L)

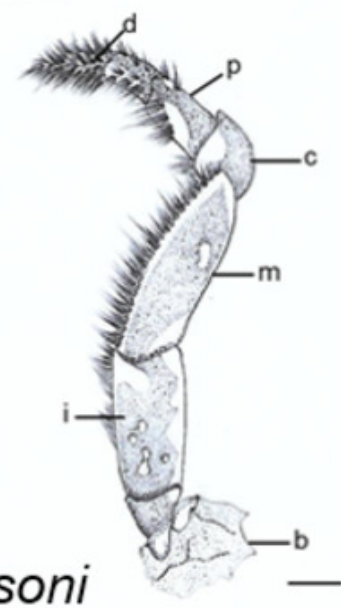




\section{Table $\mathbf{1}$ (on next page)}

Intraspecific diversity of spiny lobsters inhabiting Jeju waters.

na: data not available due to insufficient sample number. 
1 Table 1. Intraspecific diversity of spiny lobsters inhabiting Jeju waters.

\begin{tabular}{|c|c|c|c|c|c|c|c|c|c|}
\hline \multirow{2}{*}{ Clade } & \multirow{2}{*}{ Closest taxa } & \multirow{2}{*}{$\mathrm{N}$} & \multicolumn{4}{|c|}{$\begin{array}{c}\text { Pairwise mean distance between clades } \\
(\%)\end{array}$} & \multirow{2}{*}{ No. of haplotype } & \multirow{2}{*}{$\mathrm{Pi} \pm \mathrm{SD} \%$} & \multirow{2}{*}{$\begin{array}{c}\text { No. of } \\
\text { polymorphic } \\
\text { sites }\end{array}$} \\
\hline & & & Clade A & Clade B & Clade C & Clade D & & & \\
\hline A & Panulirus japonicus & 8 & 0 & & & & 7 & $5.0 \pm 2.0 \%$ & 59 \\
\hline $\mathrm{B}$ & Panulirus longipes & 2 & 27.6 & 0 & & & 2 & $0.6 \pm 0.2 \%$ & 5 \\
\hline $\mathrm{C}$ & Panulirus stimpsoni & 6 & 41.7 & 34.2 & 0 & & 4 & $2.4 \pm 1.2 \%$ & 8 \\
\hline $\mathrm{D}$ & Panulirus homarus homarus & 1 & 33.5 & 38.0 & 25.3 & 0 & na & na & na \\
\hline
\end{tabular}

2 na: data not available due to insufficient sample number. 


\section{Table 2 (on next page)}

The comparative morphological identification features of spiny lobster species collected from Jeju Island and other two species which is previously reported from South Korea. 
1 Table 2. The comparative morphological identification features of spiny lobster species collected from Jeju Island and other two 2 species which is previously reported from South Korea.

\begin{tabular}{|c|c|c|c|c|c|c|c|}
\hline Feature & $\begin{array}{l}\text { P. japonicus } \\
\text { (Jeju type) }\end{array}$ & $\begin{array}{l}\text { P. japonicus } \\
\text { (George \& } \\
\text { Holthuis, 1965) }\end{array}$ & $\begin{array}{l}\text { P. homarus } \\
\text { homarus }\end{array}$ & P. longipes & P. stimpsoni & P. penicilliatus & P. versicolor \\
\hline $\begin{array}{l}\text { No. of examined } \\
\text { specimens }\end{array}$ & 4 & 4 & 1 & 2 & 6 & na & na \\
\hline Color of carapace & Reddish brown & Reddish brown & $\begin{array}{l}\text { Brownish to } \\
\text { greenish }\end{array}$ & $\begin{array}{l}\text { Dark brown with } \\
\text { white and orange } \\
\text { color spots }\end{array}$ & $\begin{array}{l}\text { Brownish to olive } \\
\text { green }\end{array}$ & $\begin{array}{l}\text { Reddish brown } \\
\text { with many pale } \\
\text { yellow spots }\end{array}$ & $\begin{array}{l}\text { Brownish to } \\
\text { greenish and } \\
\text { black blotches } \\
\text { defined with } \\
\text { white lines }\end{array}$ \\
\hline $\begin{array}{l}\text { Cross bands in } \\
\text { antennular flagella }\end{array}$ & No cross bands & No cross bands & Cross banded & Cross banded & Cross banded & No cross bands & $\begin{array}{l}\text { No cross } \\
\text { bands }\end{array}$ \\
\hline $\begin{array}{l}\text { Spines on } \\
\text { antennular plate }\end{array}$ & $\begin{array}{l}\text { Separated } \\
\text { medium size } 02 \\
\text { spines }\end{array}$ & $\begin{array}{l}\text { Separated medium } \\
\text { size } 02 \text { spines }\end{array}$ & $\begin{array}{l}\text { Separated } 04 \\
\text { spines }\end{array}$ & $\begin{array}{l}\text { Separated } 04 \\
\text { spines }\end{array}$ & $\begin{array}{l}\text { Separated } 04 \\
\text { spines, frontal } \\
\text { pair is larger than } \\
\text { hind }\end{array}$ & $\begin{array}{l}04 \text { equal size } \\
\text { spines fused at } \\
\text { the base }\end{array}$ & $\begin{array}{l}\text { Separated } 2 \\
\text { pairs of spines } \\
\text { which is } \\
\text { unequal in size }\end{array}$ \\
\hline $\begin{array}{l}\text { Nature of the } \\
\text { ventrolateral } \\
\text { margin of the } \\
\text { carapace }\end{array}$ & $\begin{array}{l}\text { Reddish brown } \\
\text { soft surfaced line } \\
\text { with white } \\
\text { blotches }\end{array}$ & $\begin{array}{l}\text { Reddish brown soft } \\
\text { surfaced line with } \\
\text { white blotches }\end{array}$ & $\begin{array}{l}\text { Pale white line } \\
\text { edging with } \\
\text { numerous soft } \\
\text { hairs }\end{array}$ & $\begin{array}{l}\text { Reddish dark } \\
\text { brown line }\end{array}$ & $\begin{array}{l}\text { White line and } \\
\text { another white } \\
\text { line over it }\end{array}$ & $\begin{array}{l}\text { Reddish brown } \\
\text { soft surfaced } \\
\text { line with white } \\
\text { blotches }\end{array}$ & $\begin{array}{l}\text { Pale white line } \\
\text { with black line } \\
\text { over it }\end{array}$ \\
\hline $\begin{array}{l}\text { Color of frontal } \\
\text { horns }\end{array}$ & $\begin{array}{l}\text { Dorsal surface is } \\
\text { dark greenish } \\
\text { brown with white } \\
\text { spots, Ventral } \\
\text { side is orange } \\
\text { color }\end{array}$ & $\begin{array}{l}\text { Dorsal surface is } \\
\text { dark greenish } \\
\text { brown with white } \\
\text { spots, Ventral side } \\
\text { is orange color }\end{array}$ & $\begin{array}{l}\text { Tips are orange, } \\
\text { pseudo bands } \\
\text { made by white } \\
\text { spots }\end{array}$ & $\begin{array}{l}\text { brown in color, } \\
\text { tips are orange }\end{array}$ & $\begin{array}{l}\text { reddish brown } \\
\text { with pale yellow } \\
\text { four cross lines } \\
\text { and tips }\end{array}$ & $\begin{array}{l}\text { Dark brown } \\
\text { dorsal surface } \\
\text { with pale white } \\
\text { tips }\end{array}$ & $\begin{array}{l}\text { Dark brownish } \\
\text { to black with } \\
\text { white lines }\end{array}$ \\
\hline $\begin{array}{l}\text { Spins behind the } \\
\text { frontal horns }\end{array}$ & $\begin{array}{l}02 \text { medium size } \\
\text { spines with } 03 \\
\text { conspicuous } \\
\text { small spines in- } \\
\text { between }\end{array}$ & $\begin{array}{l}02 \text { medium size } \\
\text { spines with } 03 \\
\text { conspicuous small } \\
\text { spines in-between }\end{array}$ & $\begin{array}{l}02 \text { medium size } \\
\text { spines, no small } \\
\text { spines in-between }\end{array}$ & $\begin{array}{l}02 \text { medium size } \\
\text { spines with } 04 \\
\text { conspicuous small } \\
\text { spines in-between }\end{array}$ & $\begin{array}{l}02 \text { medium size } \\
\text { spines, no small } \\
\text { spines in- } \\
\text { between }\end{array}$ & $\begin{array}{l}02 \text { medium size } \\
\text { spines }\end{array}$ & $\begin{array}{l}02 \text { medium } \\
\text { size spines, no } \\
\text { small spines } \\
\text { in-between }\end{array}$ \\
\hline $\begin{array}{l}\text { Spines in the } \\
\text { frontal edge of the } \\
\text { epistome }\end{array}$ & $\begin{array}{l}03 \text { spines with } \\
\text { spinules in- } \\
\text { between }\end{array}$ & $\begin{array}{l}03 \text { spines with } \\
\text { spinules in- } \\
\text { between }\end{array}$ & $\begin{array}{l}03 \text { spines, no } \\
\text { spinules in - } \\
\text { between }\end{array}$ & $\begin{array}{l}03 \text { main spines } \\
\text { and many } \\
\text { spinules in- } \\
\text { between }\end{array}$ & $\begin{array}{l}03 \text { spines, no } \\
\text { spinules in- } \\
\text { between, middle } \\
\text { is larger than side } \\
\text { spines }\end{array}$ & $\begin{array}{l}03 \text { spines with } \\
\text { spinules in- } \\
\text { between }\end{array}$ & na \\
\hline
\end{tabular}


Table 2. (Continue)

\begin{tabular}{|c|c|c|c|c|c|c|c|}
\hline Feature & $\begin{array}{l}\text { P. japonicus } \\
\text { (Jeju type) }\end{array}$ & $\begin{array}{l}\text { P. japonicus } \\
\text { (George \& } \\
\text { Holthuis, 1965) }\end{array}$ & $\begin{array}{l}\text { P. homarus } \\
\text { homarus }\end{array}$ & P. longipes & P. stimpsoni & P. penicilliatus & P. versicolor \\
\hline $\begin{array}{l}\text { Color of abdominal } \\
\text { segments }\end{array}$ & Greenish brown & Greenish brown & Olive green & $\begin{array}{l}\text { Dark brown with } \\
\text { pale white spots }\end{array}$ & Greenish & $\begin{array}{l}\text { Greenish } \\
\text { brown }\end{array}$ & $\begin{array}{l}\text { Brownish blue } \\
\text { with white } \\
\text { lines along the } \\
\text { posterior } \\
\text { margin of each } \\
\text { somite }\end{array}$ \\
\hline $\begin{array}{l}\text { Presence of } \\
\text { transverse grooves } \\
\text { on abdominal } \\
\text { segments }\end{array}$ & $\begin{array}{l}\text { Non-interrupted } \\
\text { transverse } \\
\text { grooves }\end{array}$ & $\begin{array}{l}\text { Non-interrupted } \\
\text { transverse grooves }\end{array}$ & $\begin{array}{l}\text { Non-interrupted } \\
\text { transverse } \\
\text { grooves and } \\
\text { anterior margins } \\
\text { are crenulated }\end{array}$ & $\begin{array}{l}\text { Non-interrupted } \\
\text { transverse grooves } \\
\text { with a middle } \\
\text { notch on } 2^{\text {nd }}, 3^{\text {rd }} \\
\text { and } 4^{\text {th }} \text { segments }\end{array}$ & $\begin{array}{l}\text { No transverse } \\
\text { grooves }\end{array}$ & $\begin{array}{l}\text { Non- } \\
\text { interrupted } \\
\text { transverse } \\
\text { grooves }\end{array}$ & $\begin{array}{l}\text { No transverse } \\
\text { grooves }\end{array}$ \\
\hline $\begin{array}{l}\text { Connection } \\
\text { between transverse } \\
\text { grooves and } \\
\text { pleural grooves }\end{array}$ & $\begin{array}{l}\text { They are not } \\
\text { connected in } \\
\text { second somite } \\
\text { (but very close to } \\
\text { the pleural } \\
\text { groove) }\end{array}$ & $\begin{array}{l}\text { They are not } \\
\text { connected in } \\
\text { second and third } \\
\text { somites (distinct } \\
\text { space between } \\
\text { pleural and } \\
\text { transverse grooves) }\end{array}$ & $\begin{array}{l}1^{\text {st }} \text { transverse } \\
\text { groove connect to } \\
\text { the pleural } \\
\text { groove with } \\
\text { vertical shape and } \\
\text { others connect } \\
\text { the with different } \\
\text { articulations like } \\
\text { scalloped } \\
\text { margins }\end{array}$ & $\begin{array}{l}\text { Transvers groves } \\
\text { are connect to the } \\
\text { pleural grove in } \\
\text { each somite }\end{array}$ & Not applicable & Not connected & Not applicable \\
\hline $\begin{array}{l}\text { Presence of exopod } \\
\text { in } 2^{\text {nd }} \text { maxilliped }\end{array}$ & Present & Present & Present & Present & Present & Present & Present \\
\hline $\begin{array}{l}\text { Presence of exopod } \\
\text { in and } 3^{\text {rd }} \\
\text { maxilliped }\end{array}$ & Present & Present & Absent & Present & Absent & Absent & Absent \\
\hline
\end{tabular}

